\title{
HOW TO AUGMENT TASK AND CONTEXTUAL PERFORMANCE THROUGH EMPLOYEE ENGAGEMENT
}

\author{
Bilal Khalid ${ }^{\mathbf{1}}$ \\ Ph.D Scholar \\ Dr. Muhammad Zia urRehman ${ }^{2}$ \\ Assistant professor \\ Rana Jimshaid Asghar ${ }^{3}$ \\ Research Coordinator
}

\begin{abstract}
Objective: The basic aim of the present study is to examine the impact of vigor and dedication on task as well as on contextual performance of employees in telecom sector of Pakistan. Human asset play their role as backbone in the organization, that's why organizations in current era focusing on their development and engagement at workplace.

Methodology: The present study based on 230 respondents (middle level managers) from private telecom organizations of Islamabad/Rawalpindi.

Findings: results of the study show that vigor and dedication positively and significantly affect task and contextual performance of employees.

Practical Implication: The present study is beneficial for the management of the Telecom sector within Islamabad/Rawalpindi as well as for other relevant settings. The future study should take into account the other dimensions of engagement and performance, replication of this study in other settings (service oriented / manufacturing organizations) are also recommended.
\end{abstract}

Key Words: Workplace Bullying, Perceived Co-worker Support, Counterproductive work Behaviors.

* The material presented by the author does not necessarily portray the viewpoint of the editors and the management of the Institute of Business \& Technology (IBT)

1. Bilal Khalid

2. Dr. M. Zia Rehman

3. Rana Jimshaid Asghar
: bilalkhalid797@gmail.com

:drziaemail@gmail.com

:jimshaidasghar@gmail.com

(C) IBT-JBS is published by the Institute of Business and Technology (IBT). Main Ibrahim Hydri Road, Korangi Creek, Karachi-75190, Pakistan. 


\section{INTRODUCTION}

In the $21^{\text {st }}$ century organizations are more focusing on organizational effectiveness through engagement of employees.According toSaxena and Srivastava (2015) informed that in the recent age of technology, generally, organizations focusing on engaging employee, because engaged workforce intellectual and emotionally attached with organizations. Furthermore, they stated that the concept of employee engagement is being developed still, and organizations must focus on this phenomenon. Gupta, Acharya and Gupta (2015) argued that in the business context engagement of employees is widely debatable phenomenon in order to achieve organizational goals. Until or unless employees at workplace not engaged fully, organizations can't achieve their targeted object overall (Rich, Lepine, Crawford, 2010). According to Kompaso and Sridevi (2010) engagement of employees play its pivotal role in boosting organizational effectiveness based on performance level of employees (task and contextual).

Storey (2009) supported the work of Morgan (2004) regarding engagement of employees, which is based on different level of skills and competencies. According to Macey and Schneider (2008) organizations think that through the edge of engagement of employees, they can get competitive advantage in the competing era, as employee engagement helps in boosting performance of employees. Humphreys (2002) argued that for better employee and organizational performance in the organizational setting it is very important to understand attachment of managers towards organization as they influence other employees at workplace.

\section{LITERATURE REVIEW}

\subsection{Employee Engagement}

Almost all organizations want to get competitive advantage through retention of human talent, engaging employees in their work no doubt is very difficult task but due to their engagement organizations move upward in the market (Selvarani \& Punitha, 2015). According to Chughtai and Lateef (2015) stated that when managers/supervisors at workplace encourage their employees, ultimately employees will respond in a proactive approach toward their work, ultimately it will affect performance of the organizations. Bakker and Leiter (2010 cited Saxena\& Punitha, 2015) found that when employees feel meaningful work at workplace then definitely they will engage more. A study conducted by Khan and Iqbal (2013) found and reported that actual organizational performance is based on the performance of employees which based on their level of engagement at workplace, employers just give guidelines to employees who act in an organized manner follow those guidelines for achieving organizational goals. Adrew and Sofian (2012) stated that human capital (engaged workforce) within organizations play imperative role for gaining /edge competitive advantage. Researchers (Rice, Marlow, \&Masarech, 2012, pp. 4) defined employee engagement as "full employee engagement represents an alignment of maximum satisfaction for the individual with maximum contribution for the organization". Shuck and Wollard (2010) also defined the concept of engagement of employees as "an individual employee's cognitive emotional and behavioral state directed toward desired organizational outcomes". 


\subsection{Constructs of Employee Engagement}

Sarangi and Vats (2015) in their article precisely highlighted constructs / dimensions of employee engagement within organizational context as, Vigor: based on the phenomenon of employees' keenness toward their work within organization, further they highlighted Dedication: referred as employees work dedication at workplace till achievement of target goals" (pp. 226).

\subsection{Employee Performance}

According to (Shahhosseini, Silong, Ismaill\&Uli, 2012) proper implementation of measuring performance of employees resulted in organizational performance as well as individuals in working environment. Hersen (2004, pp. 375) stated that mostly studies conducted on employee performance show that it is aligned with behavioral outcome. According to Jex (2002, pp. 88) performance of employees can be defined as "all the behaviors employees engage in while at work".

\subsection{Constructs of Employee Performance}

Rich, Lepine and Crawford (2010) conducted study and found that employees' task performance affected by dimension of employee engagement in a positive manner at workplace, besides controlling of other constructs like employees' involvement, and employees' job satisfaction in an organizational setting. Sonnentag (2003) argued that ask performance of employees, augmented through engagement levels of employees at workplace. Basically, according to Rotundo and Rotman (2002) stated that task performance of employees based on their behaviors/action and contribution toward their job and it is related with production of good or services related matters.

Many researchers (Frese, Grast\& Fay, 2000; Frese, Fay, Hilburger, Leng\& Tag, 1997; Frese, Kring, Soose\&Zempel, 1996) found and reported the contextual performance as extrarole behavior of individuals. Morrison and Phelps (1999) explained that actually contextual performance of employees is the combination of different individuals' behavior at workplace. Researchers (Morrison \& Phelps, 1999; Motowidlo\& Van Scotter, 1994; Van Scotter, Motowidlo, 1996; Williams \& Anderson, 1991) found that in the organizational context both task as well alcontextual performance different in nature.

\subsection{Theoretical Framework}

\section{Figure - 1}

\subsection{Hypotheses Development}

H1: Vigor positively and significantly affects task performance.

$\mathrm{H} 2$ : Vigor positively and significantly influences contextual performance.

H3: Dedication significantly and positively augments task performance.

H4: Dedication affects contextual performance positively and significantly.

\section{RESEARCH METHODOLOGY}

The study data collected from middle level employees of telecom organizations operating in Islamabad. This study based on quantitative data, and descriptive in its nature, and the purposive sampling technique used in this study. After pilot testing, the researcher distributed 230 research questionnaires for final study among middle level management of private telecom companies (Mobilink/Warid, Ufone, Zong and Telenor) of Islamabad/Rawalpindi. The study based on different scales like employee engagement scale developed by Schaufeli, Salanova, Gonzalez-Roma and Bakker (2002), just 11 items of two dimensions (vigor-6, 
dedication-5) taken for the study, and for employee performance used task performance scale with 5-items developed by Williams and Anderson (1991), and just 5-items taken from the scale of contextual performance developed by Borman and Motowidlo (1993). The reliability of the instruments of (vigor, dedication, task and contextual performance) is $0.719,0.755$, 0.706 and 0.727 respectively, the result calculated through the usage of SPSS.

\section{RESEARCH FINDINGS}

\section{See Table 1 in Appendix}

Table-1 shows the results of the respondents in term of their ages. According to this table 79 middle level managers belong to age group of 2-30 years with percentage value 34.3 participated in the survey, while 69 employees (31-35 years) with $30.0 \%$.

\section{See Table 2 in Appendix}

Table 2 depicts that in the survey 173 males and 57 female managers participated with percentage value 75.2 and 24.8 respectively.

\section{See Table 3 in Appendix}

In terms of experience group 94 employees belong to the experience group 6-10 years with $40.9 \%$. 55 employees belong the group of 0-5 years (23.9\%), 49 employees belong to 11-15 years $(21.3 \%)$, while 26 employees belong to experience group of $16-20$ years $(11.3 \%)$ and only 6 employees from $21-25$ years group $(2.6 \%)$.

\section{See Table - 4 in Appendix}

Table-4 shows that 202 middle level managers hold Master \& higher degree while only 28 employees were just graduate with percentage value 87.8 and 12.2 respectively.

\section{Result of the Hypothesis I \& II}

\section{See Table - 5 in Appendix}

The results of correlation analysis for hypothesis-I (table-5) show that independentvariables (vigor \& dedication) positively and significantly Icorrelated with employees' task performance, as vigor and task performance correlated 0.508 , and their significance level also acceptable ( $\mathrm{p}<0.01$ ). on the other hand dedication is also positively correlated with task performance as its value 0.480 , and their significance value was 0.000 (p $<0.01)$ which is also acceptable and shows relationship between variables. The results further reveal that vigor and dedication also moderately correlated with each other as their value was $0.553(\mathrm{p}<0.01)$.

\section{See Table - 6, 7, 8 in Appendix}

The regression results for hypothesis-I \& II (depicted I table-6, 7, \& 8) show that the $\mathrm{R}$-square value is 0.315 (31\%) which means that $31 \%$ variation in task performance id due to vigor and dedication. The beta score of both variables (vigor and dedication) show that one unit change in dependent variables is due to independent variables is $0.320(32 \%)$ and $0.258(25 \%)$ respectively. While the significance value is $0.000(\mathrm{p}<0.05)$ for both variables, shows that both predictor influence criterion variable.

\section{Results of Hypothesis III \& IV}

\section{See Table - 9 in Appendix}

The correlation results (table. 9) for hypothesis-III \& IV show that both predictors of contextual performance are positively and significantly correlated with each other, as their values are vigor and contextual performance (0.540), while dedication and contextual performance (0.509), on the other hand significance values is 0.000 ( $\mathrm{p}<0.01)$ also acceptable.

\section{See Table - 10, 11, 12 in Appendix}


Regression analysis results for hypothesis-II as depicted in tables $(10,11, \& 12)$ show that $\mathrm{R}$-square value is $0.355(35 \%)$ it means that $35 \%$ variation in contextual performance is due to the nature of vigor and dedication jointly. While their beta values show that vigor impacts depended variable 0.340 (34\%), and dedication influences dependent variable $0.272(27 \%)$, and they significantly affected to the criterion variable as their significance value is $0.000(\mathrm{p}$ $<0.05)$.

\section{CONCLUSION}

Service oriented organization being developed rapidly especially in the third world countries, and organizations more engaging their employees at workplace for better and effective results. In this backdrop, the present study conducted to analyze whether vigor and dedication augment performance of employees at task and contextual level in private telecom organization. The results show that vigor and dedication play their positive and significant role in boosting employees' task and contextual performance at workplace. Vigor influences task and contextual performance more than dedication in working environment, therefore, study hypotheses (H1 to H4) accepted in the present study.

The present study might be helpful for management of service oriented organization in order to cater such favorable policies and training programs through which thy can be engaged in a better way at workplace and resultantly augment employee performance, ultimately organizational effectiveness will achieve. Future studies may be conducted on other sector like manufacturing sector or in hospitality industry with same or other dimensions of employee engagement and performance. This study was cross-sectional in its nature, in future longitudinal studies are also recommended, and future studies should be conducted on top level management as well in telecom sector of Pakistan.

\section{REFERENCES}

Andrew, O. C., \& Sofian, S. (2012). Individual factors and work outcomes of employee engagement. Procedia-Social and Behavioral Sciences, 40, 498-508.

Borman, W. C., \& Motowidlo, S. (1993). Expanding the criterion domain to include elements of contextual performance. Personnel Selection in Organizations; San Francisco: JosseyBass, 71.

Chughtai, M. W., \& Lateef, K. (2015). Role of emotional intelligence on employees performance in customer services: A case study of Telecom Sector of Pakistan. International Journal of Advance Research in Computer Science and Management Studies, 3(2), 101-108.

Frese, M., Garst, H., \& Fay, D. (2000). Control and complexity in work and the development of personal initiative (PI): A four-wave longitudinal structural equation model of occupational socialization. University of Giessen: Manuscript submitted for publication.

Frese, M., Fay, D., Hilburger, T., Leng, K., \& Tag, A. (1997). The concept of personal initiative: Oerationalization, reliability and validity in two German samples. Journal of Occupational and Organizational Psychology, 70, 139-162.

Frese, M., Kring, W., Soose, A., \& Zempel, J. (1996). Personal initiative at work: Differences between East and West Germany. Academy of Management Journal, 39(1), 37-63.

Gupta, M., Acharya, A., \& Gupta, R. (2015).Impact of work engagement on performance in Indian higher education system.Review of European Studies, 7(3), 192-201.

Hersen, M. (2004) Comprehensive Handbook of Psychological Assessment: Industrial and Organizational Commitment. John Wiley \& Sons Inc., New Jersey.

Page | 120

ISSN 2414-8393 
Humphreys, J. H. (2002). Transformational leader behavior, proximity and successful services marketing.Journal of Services Marketing, 16(6), 487-502.

Jex, M. (2002).Organizational psychology.A scientist-practioner approach.Chichester:John Willey \& Sons.

Khan, W., \& Iqbal, Y. (2013). An Investigation of the Relationship between Work Motivation (Intrinsic \& Extrinsic) and Employee Engagement: A Study on Allied Bank of Pakistan.

Kompaso, S. M., \& Sridevi, M. S. (2010). Employee engagement: The key to improving performance. International Journal of Business and Management, 5(12), p89.

Macey, W. H., \& Schneider, B. (2008).The meaning of employee engagement.Industrial and organizational Psychology, 1(1), 3-30.

Morgan, L. (2004). Driving performance and retention through employee engagement. Corporate Executive Board, 2-10.

Morrison, E. W., \& Phelps, C. C. (1999). Taking charge at work: Extrarole efforts to initiate workplace change. Academy of Management Journal, 42(4), 403-419.

Motowidlo, S. J., \& Van Scotter, J. R. (1994). Evidence that task performance should be distinguished from contextual performance. Journal of Applied Psychology, 79(4), 475.

Rice, C., Marlow, F., \& Masarech, M. A. (2012). The Engagement Equation: Leadership Strategies for an Inspired Workforce. John Wiley \& Sons.

Rich, B. L., Lepine, J. A., \& Crawford, E. R. (2010). Job engagement: Antecedents and effects on job performance. Academy of Management Journal, 53(3), 617-635.

Rotundo, M., \&Rotman, J. L. (2002). Defining and measuring individual level job performance: A review and integration. Cite Seer: An Automatic Citation Indexing System, 10, 1-72

Sarangi, S., \& Vats, A. (2015). Role of Emotional Intelligence on Employee Engagement: A Study among Indian Professionals. International Journal of Business and Management, 10(6), 224-233.

Saxena, V., \&Srivastava, R. K. (2015).Impact of employee engagement on employee performance-case of manufacturing sectors.International Journal of Management Research \& Business Strategy, 4(2), 139-174.

Schaufeli, W. B., Salanova, M., González-Romá, V., \& Bakker, A. B. (2002). The measurement of engagement and burnout: A two sample confirmatory factor analytic approach. Journal of Happiness Studies, 3(1), 71-92.

Selvarani, A., \& Punitha, K. (2015). A Study on Employee Engagement in Chettinad Cement Corporation Limited, Puliyur, Karur. International Journal of Management, 6(1), 646655.

Shahhosseini, M., Silong, A. D., Ismaill, I. A., \&Uli, J. N. (2012). The role of emotional intelligence on job performance. International Journal of Business and Social Science, 3(21), 241-246.

Shuck, B., \& Wollard, K. (2010). Employee engagement and HRD: A seminal review of the foundations. Human Resource Development Review, 9(1), 89-110.

Sonnentag, S. (Ed.). (2003). Psychological management of individual performance.John Wiley \& Sons.

Storey, J. (2009). The Routledge companion to strategic human resource management: Taylor \& Francis.

Van Scotter, J. R., \& Motowidlo, S. J. (1996). Interpersonal facilitation and job dedication as separate facets of contextual performance. Journal of Applied Psychology, 81(5), 525. 
Williams, L. J., \& Anderson, S. E. (1991). Job satisfaction and organizational commitment as predictors of organizational citizenship and in-role behaviors. Journal of Management, 17(3), 601-617.

\section{APPENDIX}

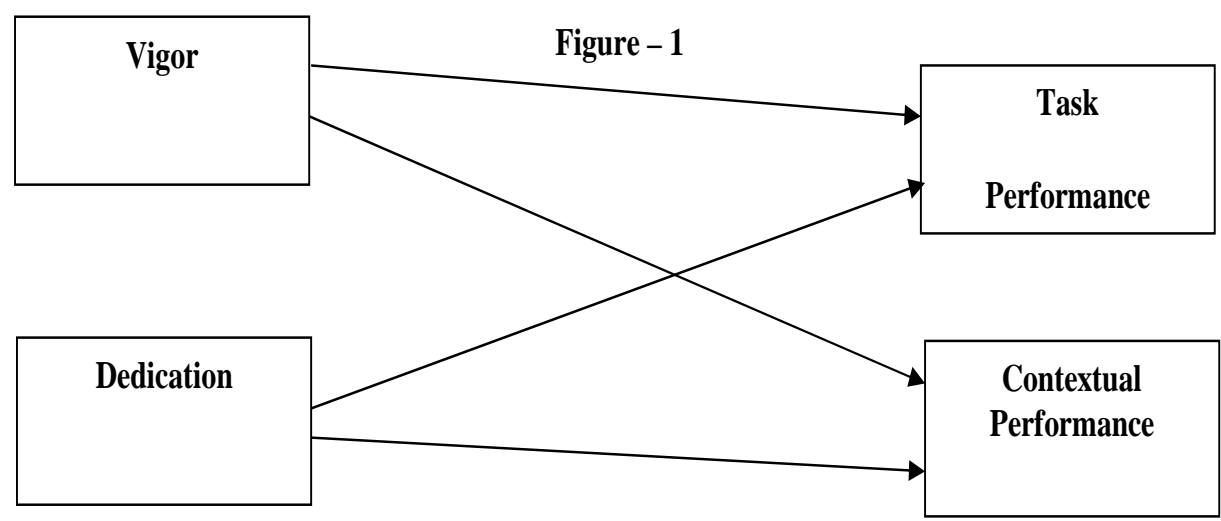

\begin{tabular}{|c|c|c|c|c|c|}
\hline \multirow{2}{*}{\multicolumn{2}{|c|}{ Table 1: }} & \multicolumn{3}{|c|}{ Ages' of Survey Participants } & \multirow[b]{2}{*}{ Cumulative Percent } \\
\hline & & Frequency & Percent & Valid Percent & \\
\hline \multirow[t]{7}{*}{ Valid } & $20-25$ & 11 & 4.8 & 4.8 & 4.8 \\
\hline & $26-30$ & 79 & 34.3 & 34.3 & 39.1 \\
\hline & $31-35$ & 69 & 30.0 & 30.0 & 69.1 \\
\hline & $36-40$ & 39 & 17.0 & 17.0 & 86.1 \\
\hline & $41-45$ & 24 & 10.4 & 10.4 & 96.5 \\
\hline & $46-50$ & 8 & 3.5 & 3.5 & 100.0 \\
\hline & Total & 230 & 100.0 & 100.0 & \\
\hline
\end{tabular}

\begin{tabular}{|l|l|c|c|c|c|}
\hline \multicolumn{4}{|c|}{ Table 2: } & \multicolumn{3}{c|}{ Gender of the Respondents } \\
\hline \multirow{2}{*}{ Valid } & Frequency & Percent & Valid Percent & Cumulative Percent \\
\cline { 2 - 6 } & Male & 173 & 75.2 & 75.2 & 75.2 \\
\cline { 2 - 6 } & Female & 57 & 24.8 & 24.8 & 100.0 \\
\cline { 2 - 6 } & Total & 230 & 100.0 & 100.0 & \\
\hline
\end{tabular}

\begin{tabular}{|c|c|c|c|c|c|}
\hline \multicolumn{6}{|c|}{ Experience of the Survey Participants } \\
\hline & & Frequency & Percent & Valid Percent & Cumulative Percent \\
\hline \multirow[t]{6}{*}{ Valid } & $0-5$ & 55 & 23.9 & 23.9 & 23.9 \\
\hline & $6-10$ & 94 & 40.9 & 40.9 & 64.8 \\
\hline & $11-15$ & 49 & 21.3 & 21.3 & 86.1 \\
\hline & $16-20$ & 26 & 11.3 & 11.3 & 97.4 \\
\hline & $21-25$ & 6 & 2.6 & 2.6 & 100.0 \\
\hline & Total & 230 & 100.0 & 100.0 & \\
\hline
\end{tabular}




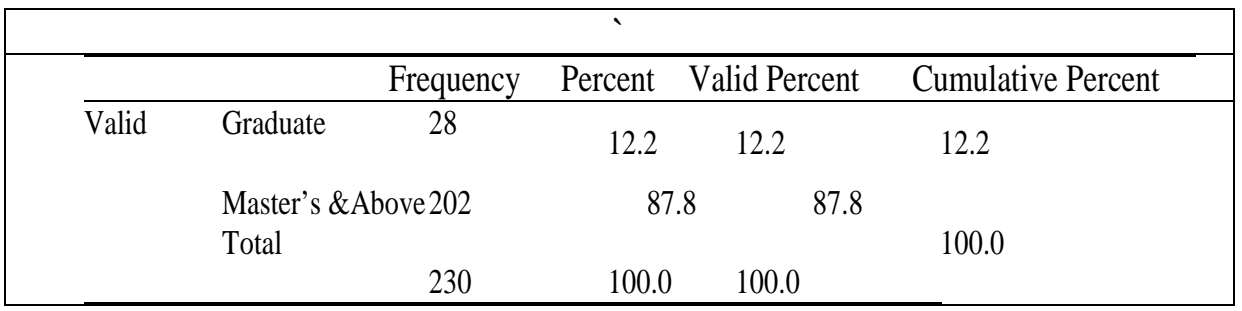

\begin{tabular}{|c|c|c|c|c|}
\hline & \multicolumn{3}{|c|}{ Correlation I \& II } & \multirow[b]{2}{*}{$\begin{array}{c}\text { Task } \\
\text { Performance }\end{array}$} \\
\hline & & Vigor & Dedication & \\
\hline Vigor & $\begin{array}{l}\text { Pearson Correlation } \\
\text { Sig. (2-tailed) } \\
\text { N }\end{array}$ & $\begin{array}{c}1 \\
230\end{array}$ & & \\
\hline Dedication & $\begin{array}{l}\text { Pearson Correlation } \\
\text { Sig. (2-tailed) }\end{array}$ & $\begin{array}{l}.553^{* *} \\
.000 \\
230\end{array}$ & $\begin{array}{c}1 \\
230\end{array}$ & \\
\hline Task Performance & $\begin{array}{l}\text { Pearson Correlation } \\
\text { Sig. (2-tailed) } \\
\text { N }\end{array}$ & $\begin{array}{l}.508^{* *} \\
.000 \\
230\end{array}$ & $\begin{array}{l}.480^{* *} \\
.000 \\
230\end{array}$ & $\begin{array}{c}1 \\
230\end{array}$ \\
\hline
\end{tabular}

\begin{tabular}{|c|c|c|c|c|c|c|c|c|c|}
\hline & & & Table & Mo & I Summa & I \& II & & & \\
\hline \multirow[t]{2}{*}{ Model } & \multirow[t]{2}{*}{$\mathrm{R}$} & \multirow{2}{*}{$\begin{array}{c}\mathrm{R} \\
\text { Square }\end{array}$} & \multirow{2}{*}{$\begin{array}{l}\text { Adjusted } \\
\text { R Square }\end{array}$} & \multirow{2}{*}{$\begin{array}{l}\text { Std. Error of } \\
\text { the Estimate }\end{array}$} & \multicolumn{5}{|c|}{ Change Statistics } \\
\hline & & & & & $\begin{array}{l}\text { R Square } \\
\text { Change }\end{array}$ & $\begin{array}{c}\mathrm{F} \\
\text { Change }\end{array}$ & df1 & $\mathrm{df2}$ & $\begin{array}{l}\text { Sig. F } \\
\text { Change }\end{array}$ \\
\hline 1 & $.561^{\mathrm{a}}$ & .315 & .309 & .58318 & .315 & 52.175 & 2 & 227 & .000 \\
\hline
\end{tabular}

\begin{tabular}{|c|c|c|c|c|c|c|}
\hline \multicolumn{4}{|c|}{ Table 7: } & \multicolumn{3}{|c|}{ ANOVA - I \& II } \\
\hline \multicolumn{2}{|c|}{ Model } & Sum of Squares & $\mathrm{df}$ & Mean Square & $\mathrm{F}$ & Sig. \\
\hline 1 & Regression & 35.490 & 2 & 17.745 & $\begin{array}{c}52.17 \\
5\end{array}$ & $.000^{\mathrm{b}}$ \\
\hline & Residual & 77.203 & 227 & .340 & & \\
\hline & Total & 112.693 & 229 & & & \\
\hline \multicolumn{7}{|c|}{ a. Dependent Variable: Task Performance } \\
\hline \multicolumn{7}{|c|}{ b. Predictors: (Constant), Dedication, Vigor } \\
\hline
\end{tabular}




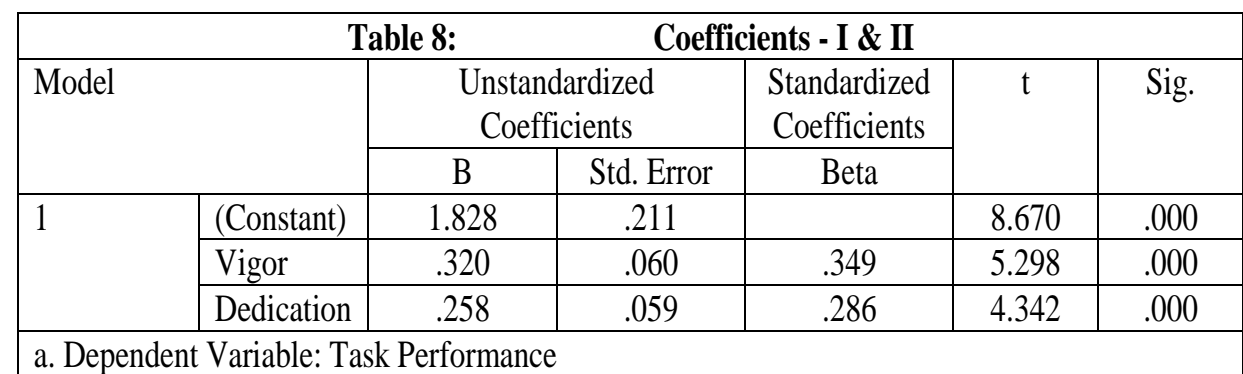

\begin{tabular}{|c|c|c|c|c|}
\hline & Table 9: & relation & III \& IV & \\
\hline & & Vigor & Dedication & $\begin{array}{l}\text { Contextual } \\
\text { Performance }\end{array}$ \\
\hline Vigor & Pearson Correlation & 1 & & \\
\hline & Sig. (2-tailed) & & & \\
\hline & $\mathrm{N}$ & 230 & & \\
\hline Dedication & Pearson Correlation & $.553^{* *}$ & 1 & \\
\hline & Sig. (2-tailed) & .000 & & \\
\hline & $\mathrm{N}$ & 230 & 230 & \\
\hline Contextual & Pearson Correlation & $.540^{* *}$ & $.509^{* *}$ & 1 \\
\hline Performance & Sig. (2-tailed) & .000 & .000 & \\
\hline & $\mathrm{N}$ & 230 & 230 & 230 \\
\hline
\end{tabular}

\begin{tabular}{|l|c|c|c|c|c|c|c|c|c|}
\hline \multicolumn{10}{|c|}{ Table 10: Model Summary- III \& IV } \\
\hline Mo \\
del
\end{tabular}

\begin{tabular}{|c|c|c|c|c|c|c|}
\hline \multicolumn{2}{|c|}{ (1) } & Table 11: & \multicolumn{2}{|c|}{ ANOVA- III \& IV } & \multirow{3}{*}{$\begin{array}{c}\mathrm{F} \\
62.514\end{array}$} & \multirow{3}{*}{$\begin{array}{l}\text { Sig. } \\
.000^{\mathrm{b}}\end{array}$} \\
\hline & & $\begin{array}{l}\text { Sum of } \\
\text { Squares }\end{array}$ & $\mathrm{df}$ & Mean Square & & \\
\hline \multirow[t]{3}{*}{1} & Regression & 39.907 & 2 & 19.954 & & \\
\hline & Residual & 72.455 & 227 & .319 & & \\
\hline & Total & 112.362 & 229 & & & \\
\hline \multicolumn{7}{|c|}{ a. Dependent Variable: Contextual Performance } \\
\hline \multicolumn{7}{|c|}{ b. Predictors: (Constant), Dedication, Vigor } \\
\hline
\end{tabular}




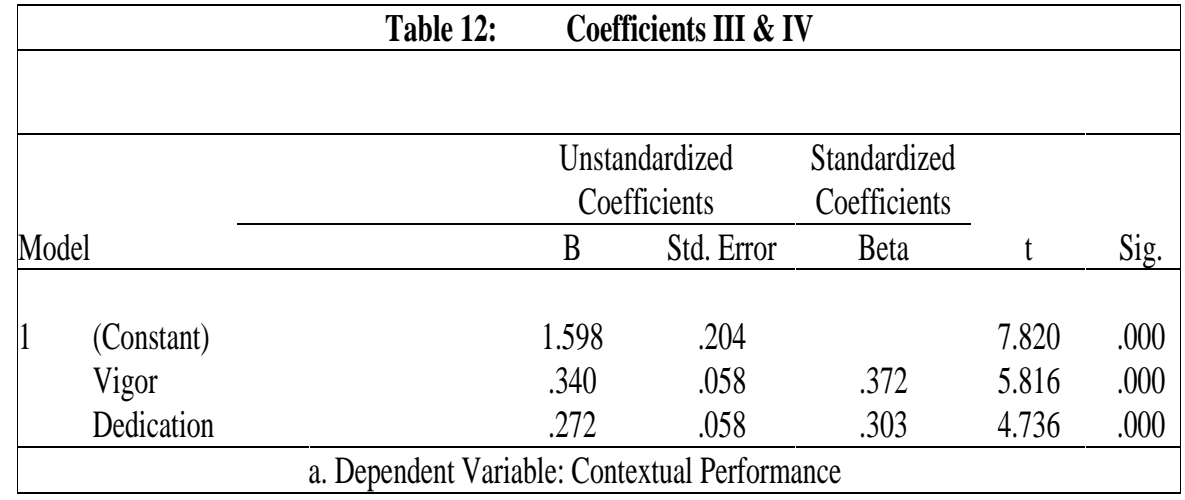

